Digital Press Social Sciences and Humanities

Public Education Through E-commerce in Increasing

Competitiveness of Small and Medium Enterprises during the Covid-19 Pandemic

Reza Gusmanti, Yanti Shantini and Ihat Hatimah

Proceeding of Non-Formal Education International Seminar 2021

Alim Harun Pamungkas, Jamaris, Solfema (eds) 


\title{
Public Education Through E-commerce in Increasing Competitiveness of Small and Medium Enterprises during the Covid-19 Pandemic
}

\author{
Reza Gusmanti*, Yanti Shantini, and Ihat Hatimah \\ Department of Community Education Universitas Pendidikan Indonesia, Bandung, Indonesia \\ *e-mail: rezagusmanti@upi.edu
}

\begin{abstract}
The COVID-19 pandemic has changed various aspects of human life today, especially in the world of the community economy. This requires all elements of society, especially small and medium business (UMKM) activists to adapt to survive during the COVID-19 pandemic. The purpose of this research is general public education through e-commerce in increasing the competitiveness of UMKM during the COVID-19 pandemic. This study used descriptive qualitative method. The population in this study are small and medium enterprises. In an effort to obtain data, information and facts in the field research, the writer uses observation, interview and documentation techniques. The results of the study show that the community needs education related to buying and selling through e-commerce, UMKM as businesses whose existence is busy in the community also have an impact.
\end{abstract}

\section{Keywords}

public education, E-commerce, small and medium enterprises

\section{Introduction}

The COVID-19 pandemic has had an impact on many parties, this condition has penetrated the world economy, many workers have been laid off and laid off due to a reduction in staff. This is done as an effort to prevent the spread of COVID-19 transmission. It is hoped that the reduction of the workforce can minimize the spread of this COVID-19 disease. Various countries have also been exposed to this COVID-19 disease. The lockdown or quarantine policy is carried out as an effort to reduce the interaction of many people who can provide access to the spread of the corona virus. The policies taken by many countries, including Indonesia by limiting all activities outside the home, have made it difficult for many affected people to work and carry out activities from outside their homes. Of course, this has an impact on mobilization and productivity, both for professionals and the general public. Covid-19 caused an economic shock that affected the economy of individuals, households, micro, small, medium, and large companies, and even affected the country's economy with local, national and even global coverage scales (Kusumastuti, 2020). Based on data from the International Labor Organization (ILO), in May 2020 it was noted that 65\% of the business world in Indonesia had stopped their company operations due to the impact of covid-19. As many as $2.6 \%$ of companies are known to have permanently stopped their operations. And as many as $62.6 \%$ have also stopped temporarily, $3 \%$ have resumed operations. The International Hunting Organization (ILO) says the potential for small companies (less than 10 employees) to go bankrupt is three times greater than that of medium and large companies (more than 50 employees). In addition, there are data that explain the proportion of MSMEs affected by the tourism sector to National MSMEs.

Covid-19 caused the business world to experience a decline in activity and income, the Central Statistics Agency (BPS) revealed the results of a survey on the impact of the Covid-19 pandemic conducted on 34,559 business actors, 82.55 percent of business actors surveyed experienced a decrease in income. Because Covid-19 has had an impact on company productivity. A total of 14.6 percent of respondents in the survey admitted that they still earned the same amount of income as before the pandemic. Then as much as 2.55 percent stated that their income actually increased. The companies that experienced the most decline in income were micro and small enterprises (UMK). The number reached 84.2 percent. Micro and small 
business actors receive the biggest impact from this COVID-19 pandemic, but on the other hand according to the Central Statistics Agency (BPS) the number of Micro, Small and Medium Enterprises (MSMEs) reaches 64 million. This figure reaches 99.9 percent of all businesses operating in Indonesia. Various steps to save MSMEs have been carried out by the government, ranging from credit restructuring, to working capital assistance from the president, but this is certainly not enough. SMEs themselves must find ways how their businesses can still exist in the midst of the COVID-19 pandemic.

Anticipating the impact of covid-19 gets the attention of the Central Government's policies and which is the epicenter of covid-19, with the dynamics of logical consequences on business activities. The presence and spread of COVID-19, whose existence is in the external environment and is not controlled (uncontrollable) or outside the control of the company, is considered to contribute to determining whether or not a business entity survives. West Sumatra is one of the provinces with a fairly rapid business turnover in Indonesia, has implemented social distancing, work from home (WFH) policies and large-scale social restrictions (PSBB) for local government officials, companies, the education sector and reducing the intensity of public transportation. . This policy is an effort to reduce the spread of COVID-19 which, if not controlled, will have a bigger and prolonged negative effect. The increase in the coronavirus has triggered the economic downturn of society as a whole and cut off the supply chain of businesses where production and producers have become more constrained. Small and medium enterprises are at the forefront of the economic shock caused by the COVID-19 pandemic. With the lockdown policy, the sudden stop of economic activity prompted a change in manual transactions to the online system. Buying and selling online is the right solution in maintaining income stability and family welfare The increase in the coronavirus has triggered the economic downturn of society as a whole and cut off the supply chain of businesses where production and producers have become more constrained. Small and medium enterprises are at the forefront of the economic shock caused by the COVID-19 pandemic. With the lockdown policy, the sudden stop of economic activity prompted a change in manual transactions to the online system. Buying and selling online is the right solution in maintaining income stability and family welfare The increase in the coronavirus has triggered the economic downturn of society as a whole and cut off the supply chain of businesses where production and producers have become more constrained. Small and medium enterprises are at the forefront of the economic shock caused by the COVID-19 pandemic. With the lockdown policy, the sudden stop of economic activity prompted a change in manual transactions to the online system. Buying and selling online is the right solution in maintaining income stability and family welfare (Husain, Wahyudi, Safi'i, \& Zarlis, 2020).

E-commerce as an online buying and selling trend, people prefer to shop online or online through online stores or online shops. Actually, this shopping culture has existed for a long time, but its intensity is getting higher as the number of cases of COVID-19 is increasing. This can be a gap for economically affected communities to rise up, by starting a business or developing an online store. With the existence of sophisticated technology, all age groups from teenagers to the elderly can certainly operate online stores easily according to their respective strategies. With the emergence of new habits of society, small and medium businesses that initially made buying and selling transactions directly through stores had to switch to buying and selling online (Wardani, Diana, Febriyanto, Khasanah, \& Nugraha, 2020). This study aims to see the importance of education for the community with the emergence of new habits of society with online buying and selling activities through e-commerce for small and medium businesses.

\section{Methods}

The research method used is descriptive qualitative method based on secondary data from research results and literature references regarding data and information related to research. Data collection techniques use documentation techniques as a way for researchers to collect data from various reference sources. The type of data in the form of secondary data in the form of qualitative and quantitative data from journals and online news. Secondary data is data that refers to information collected from existing sources. Secondary data sources are company records or documentation, government documentation or government publications, industry analysis by media, websites, and others. The location to be studied is the Province of West Sumatra, namely the owners of small and medium enterprises (UMKM). In an effort to obtain data, information and facts in the field research, the writer uses the following techniques: 1) Observation; Data collection is done by direct observation to obtain the necessary data, which is related to the subject matter. 2) Interview; Data collection was obtained by taking information and direct questions and answers with related parties, in this case interviews were conducted with the owner/leader of each airguci craftsman. 3 ) 
Documentation; Data obtained by studying books to get the basics needed in solving research problems, such as previous research (journals, theses, newspapers, etc.), data obtained from the internet, as well as data obtained from the research location. Technical data analysis in qualitative analysis focuses more on the use of words, where the analysis activities are divided into 3 parts, namely: 1) Data reduction which is an analysis to sharpen, classify, direct, discard what is considered unnecessary, and clarify/group, so that the data that is obtained, conclusions can be drawn. The purpose of this reduction is to simplify and transform in various ways. 2) Data presentation; This stage is the second activity after reducing the data obtained and the data that has been reduced or grouped are rearranged so that the data is neatly organized and easy to understand. 3) And drawing conclusions; At this final stage is the analysis activity, the analysis activity is drawing conclusions / verification, based on the data obtained from the study, the researcher began to detail the meaning, both from the results of patterns, configurations, explanations obtained from the results of interviews, looking for a tool for cause and effect and prepositions. This was done to get a conclusion. The reason for this verification stage is drawing conclusions and re-verification or verification which aims to seek truth and approval, so that the validity of the data can be achieved in accordance with expectations (Huberman, Saldana, \& Miles, 2014).

\section{Results and Discussion}

Indonesia's economic development at this time is directed at an independent and reliable national economy to improve the welfare of all people in a broad, fair and equitable manner. Economic growth must be directed at increasing people's income, and needs special attention, both from the government and private parties and related agencies. One of the industries currently being promoted is the creative economy. The definition of the creative economy to date has not been clearly formulated. Creativity, which is a vital element in the creative economy itself, is still difficult to distinguish whether it is a process or an innate human character. The Ministry of Trade of the Republic of Indonesia in 2008 formulated the creative economy as a sustainable economic development effort through creativity with an economic climate that is competitive and has reserves of renewable resources. A clearer definition is presented by UNDP in 2008 which formulates that the creative economy is an integrative part of innovative knowledge, creative use of technology, and culture. In the context of developing the creative economy in cities in Indonesia, the creative industry has more potential to develop in big cities or cities that have been "known". This is related to the availability of reliable human resources and also the availability of a better marketing network compared to small cities. However, this does not rule out the possibility of small cities in Indonesia to develop the creative economy. Judging from the breadth of the scope of the creative economy, most of them are economic sectors that do not require large scale production. Unlike the manufacturing industry, which is oriented to the quantity of products, the creative industry relies more on the quality of human resources. In fact, more creative industries emerge from small and medium industry groups (UMKM).

\subsection{Use of Online Shop / E-Commerce}

Based on the results of field observations and supported by data from interviews with creative industry players or UMKM, it is known that the use of e-commerce has been carried out by these two craft business actors, namely ethnic Borneo and online gem shops. An e-commerce system has been applied to UMKM in West Sumatra Province. This was confirmed by one of the clothing store owners, who stated that the use of online / e-commerce stores could promote their products, namely the embroidery of airguci, which was carried out, following the interview excerpts:

"We have been using online stores for the past 4 years, this form of buying and selling really helps us in selling the products we offer. There are so many benefits that we can use this e-commerce, because of the promotion through the internet, more and more people know, what is embroidered airguci that people still don't understand, we use Facebook, twitter, blog, email, blackberry messenger applications. (Interview $1 / 06 / 2021)$.

From what was described by the owner of this shop, in accordance with the marketing concept, which is one of the main activities that need to be carried out by companies, whether goods or services companies in an effort to maintain the viability of their business. This is because marketing is one of the company's activities, which are directly related to consumers. So, marketing activities can be interpreted as human activities that take place in relation to the market. Kotler, Kartajaya and Setiawan (2010) put forward the 
definition of marketing means working with target markets to realize potential exchanges with the intention of satisfying human needs and wants. So, it can be said that the success of marketing is the key to the success of a company.

"Using an online store / e-commerce / Facebook, twitter, blog, email, blackberry messenger has more advantages than disadvantages, many consumers, especially those from outside the region can see directly on our web display" (interview 1/06/2021)

"In addition, consumers can also order directly, without having to bargain and can directly order our products (interview $11 / 1 / 2021$ )

Based on the above opinion, this is in accordance with the Marketing Concept, namely Marketing is an important factor to achieve success for companies will know there are ways and philosophies involved in it. This new way and philosophy are called the marketing concept. The marketing concept is created using three basic factors, namely: a) The planning channels and company activities must be consumer/market oriented. b) Profitable sales volume should be the company's goal, and not volume for the sake of volume itself. c. All marketing activities within the company must be coordinated and integrated organizationally. according to Swastha and Irawan (2005) the marketing concept as a business philosophy which states that the satisfaction of consumer needs is an economic and social condition for the survival of the company. The marketing department in a company plays a very important role in order to achieve a large sales volume, because the achievement of the desired sales volume means that the performance of the marketing department in introducing the product has been running correctly. Sales and marketing are often thought of as the same but are actually different. The main purpose of the marketing concept is to serve consumers by getting some profit, or it can be interpreted as a comparison between income and reasonable costs. This is different from the sales concept which focuses on the company's desires.

\subsection{Public education in increasing the competitiveness of UMKM}

The Indonesian people are considered to still need education to become consumers of electronic commerce or e-commerce. The majority of Indonesian consumers are community online shoppers. With the rapid development of e-commerce, UMKM are impacted, which initially sell directly, now have to move to applications via e-commerce (Jalius, Sunarti, Azizah, \& Gusmanti, 2019). E-commerce is considered an effective solution in increasing and awakening the competitiveness of buying and selling during the covid19 pandemic census data from the Central Statistics Agency (BPS) states that in the last 10 years the ecommerce industry in Indonesia has increased by 17 percent with the total number of e-commerce businesses reaching 26.2 million units. With the increase in people's income through e-commerce, this is in line with the current conditions in the midst of the COVID-19 pandemic which limits activities outside the home. So, the order of human life has changed, through e-commerce it is hoped that SME activists can increase their competitiveness in the midst of this covid-19 pandemic. The high demand for online learning is an opportunity for UMKM activists to stay on the axis during the pandemic.

E-commerce in Indonesia still has several challenges, including the number of local products that are still out of quantity compared to imported products and consumer education about safe online shopping transactions, E-commerce operators in Indonesia are also required to provide solutions or services that are safe to use for their users (Irayani \& Ayuningsasi, 2021). Users or consumers are also protected by Law No. 8 of 1999 concerning Consumer Protection. The government will also strengthen supervision of this online trade. Business actors engaged in the UMKM sector are also expected to understand the existing regulations so that they can run their business calmly and be able to see the opportunities that exist amid the increasing competitiveness of online buying and selling through e-commerce. E-commerce by utilizing an electronic technology that is connected between companies, consumers and the public in the form of electronic transactions and the exchange/sale of goods, services and information electronically. Based on the usefulness of e-commerce, it is necessary to educate the public regarding this adaptation change, both the community as buyers and sellers. First, let's provide insight into the digital economy through the ranks of local governments to the community, especially SME players through business development education seminars, leading those who initially only used to sell conventionally, can also use digital methods through e-commerce. Not only for UMKM the government is also expected to invite villagers to want to learn about technological developments, especially the internet for the initial stage of introduction to the digital economy. First, let us provide insight into the digital economy through the ranks of local governments to the community, especially SME players through business development education seminars, leading those who initially only used to sell conventionally, can also use digital methods through e-commerce. Not only for SMEs, but the government is also expected to invite villagers to want to learn about technological developments, especially the internet for the initial stage of introduction to the digital economy. First, let's 
provide insight into the digital economy through the ranks of local governments to the community, especially SME players through business development education seminars, leading those who initially only used to sell conventionally, can also use digital methods through e-commerce. Not only for SMEs, but the government is also expected to invite villagers to want to learn about technological developments, especially the internet for the initial stage of introduction to the digital economy.

Public education related to the use of e-commerce can be done through local governments or the government can educate urban communities to rural communities, for example with assistance or mediation, such as students. With the real work college program (I Gusti Ayu Irayani, Anak Agung Ketut Ayuningsasi2, 2021). With this way of education every year there will be many people who can be educated from this activity. Furthermore, residents can also be directed to make sales to startups that run in the livestock or agriculture sector so that marketing will be further improved, and products will be more widely known. With this opinion, the public has a great opportunity to develop their business from conventional to digital by participating in advancing the digital economy in Indonesia.

Another interesting option is with public service advertisements, this delivery can be done in a unique way so that people are interested and willing to take advantage of the digital economy positively to encourage economic growth, for example the government through the communications and information technology or bekraf can collaborate with workers in the digital economy as described above. Nowadays, one of the examples is content creator.

Why does this need to be done? Because if the government only informs a movement only through the website of a government agency or news media, people will not be much interested in seeing the possibility of them just skimming because it feels boring, so collaboration with content creators delivering information will be more interesting, making many people become interested in what they have to say. This has proven to be effective, just note that private companies are now collaborating with them a lot because the content that is created is very attractive so it can attract a lot of attention, not to mention if the content creator who is invited to collaborate has a lot of followers on their social media.

Optimization that the government can also carry out such collaborations so as to attract people's attention to participate in the digital economy ecosystem, especially for the productive millennial generation. They can use or take advantage of the digital economy to do many positive things, from using available platforms such as ride-hailing applications to travel or ordering food and drinks. Then use ecommerce as a digital business medium, not only for millennial but also for UKM so that their products can be known more widely. Using digital payment applications to make buying and selling (Ambarwati \& Sobari, 2020; Christian, 2017).

The conclusion is that the development of the digital economy through e-commerce in Indonesia will continue to increase during the COVID-19 pandemic, people need to mentally prepare for this change in the order of life. MSME activists as providers of goods and services for community needs that penetrate from cities to villages can increase their competitiveness during the COVID-19 pandemic. With the ease of transactions and a lot of interest from the public regarding online buying and selling, the limited activities outside the home will keep UMKM on the axis in increasing their competitiveness.

\section{Conclusion}

The COVID-19 pandemic is an event whose existence is in an external environment that is relatively uncontrollable or beyond the control of the company. The direct impact that affects business entities is related to conventional business activities in the fields of marketing, finance, human resources and operations. The business sectors whose development was constrained and even experienced a decline during the COVID-19 pandemic were the transportation, tourism, shopping centers, and offline trade businesses which only focused on direct consumer visits. Business activities that can still survive and exist to serve consumers (transformed using online application platforms) are education, retail, staple foodstuffs. E-commerce provides a role for Indonesia's economy during the Covid-19 pandemic is good for small and medium businesses (UMKM) consumers, and the government. For business players, e-commerce is a solution to overcome the impact of Covid-19, increasing scale effort, improve understanding community regarding online buying and selling, community behavior, and encouraging people to be able to adapt to conditions during the pandemic and technology. E-commerce is also beneficial for consumers including providing security and convenience in transactions because they still comply with health protocols. Consumers are also more effective and efficient in terms of time, effort, and price selection 
compared to conventional transactions. With the development of e-commerce, it also has an impact on the development of technology for e-commerce meet consumer needs.

\section{References}

Ambarwati, A., \& Sobari, I. S. (2020). Membangun Jiwa Kewirausahaan Di Era Milenial Bagi ahasiswa Institut Stiami Kampus Tangerang Selatan. Jurnal Komunitas: Jurnal Pengabdian Kepada Masyarakat, 2(2), 140-144. https://doi.org/https://doi.org/10.31334/jks.v2i2.736

Christian, M. (2017). Pengaruh Faktor Perilaku Pada Kelompok Millineal Terhadap Keinginan Untuk Berwirausaha. Journal of Business \& Applied Management, 10(2), 92-105. https://doi.org/10.30813/jbam.v10i02.930

Huberman, A. M., Saldana, J., \& Miles, M. B. (2014). Qualitative Data Analysis (T. Rohindi, trans.). Depok: UI Press.

Husain, H., Wahyudi, M., Safi'i, M., \& Zarlis, M. (2020). E-Bisnis Solusi Inovatif Penggerak Ekonomi Masyarakat Pandemi Covid 19. Prosiding Seminar Nasional Riset Dan Information Science (SENARIS), (2), 100-104.

Irayani, I. G. A., \& Ayuningsasi, A. A. K. (2021). Pengaruh Tingkat Pendidikan Dan Jenis Produk Terhadap Pemanfaatan E-commerce Dan Omzet Penjualan Pada UMKM Di Kota Denpasar. E-Jurnal EP Unud, 10(2), 658-685. Retrieved from https://ojs.unud.ac.id/index.php/eep/article/view/60632

Jalius, J., Sunarti, V., Azizah, Z., \& Gusmanti, R. (2019). Implementation of Life Skills in Order to Add Family Income and Contributions to Empowerment of Women. KOLOKIUM: Jurnal Pendidikan Luar Sekolah, 7(2), 154-159. https://doi.org/https://doi.org/10.24036/kolokium-pls.v7i2.354

Kotler, P., Kartajaya, H., \& Setiawan, I. (2010). Marketing 3.0: Mulai dari Produk ke Pelanggan ke Human Spirit. Jakarta: Erlangga.

Kusumastuti, A. D. (2020). Pengaruh Pandemi Covid-19 terhadap Eksistensi Bisnis UMKM dalam Mempertahankan Business Continuity Management (BCM). E-Journal Administrasi Bisnis, 8(3), 224232. Retrieved from http://e-journals.unmul.ac.id/index.php/jadbis/article/view/4188

Swastha, B., \& Irawan. (2005). Asas-asas Marketing. Liberty.

Wardani, C. W., Diana, M. E., Febriyanto, M. A., Khasanah, N. U., \& Nugraha, R. D. O. (2020). Pelatihan Ecommerce sebagai Solusi Perbaikan Perekonomian di Masa Pandemi Covid. Semarang. Retrieved from https://kkn.unnes.ac.id/lapkknunnes/32004_3322152008_6_Desa 